\title{
Emergent Readers and the Joy of Reading: A Finnish Perspective
}

\author{
Juli-Anna Aerila, Tuula Merisuo-Storm \\ Department of Teacher Education, University of Turku, Turku, Finland \\ Email: julaer@utu.fi, tuumer@utu.fi
}

How to cite this paper: Aerila, J.-A., \& Merisuo-Storm, T. (2017). Emergent Readers and the Joy of Reading: A Finnish Perspective. Creative Education, 8, 2485-2500. https://doi.org/10.4236/ce.2017.815171

Received: November 21, 2017

Accepted: December 23, 2017

Published: December 26, 2017

Copyright $\odot 2017$ by authors and Scientific Research Publishing Inc. This work is licensed under the Creative Commons Attribution International License (CC BY 4.0).

http://creativecommons.org/licenses/by/4.0/

\section{c) (i) Open Access}

\begin{abstract}
Good reading skills are an essential part of everyday life. This article presents two Finnish projects JEKKU (2010-2011) and LUKUINTO (2012-2015) that aim to enhance children's engagement and success in reading. The research results of these studies are described in this article from three perspectives: reading skills, reading materials, and reading interventions. The main aim of this article is to highlight how helping children to read and enjoy reading is not complicated. Our studies show that children who are interested in what they read, and experience pleasure and success while reading, are provided with comfortable reading places and enough time to concentrate on reading, read more and become confident readers. The basics of reading skills and the attitudes towards reading are created in the early years, so it is important to concentrate on making these reading experiences more interesting and enjoyable for all young children. This article is not a traditional research article, but collects the results of the two projects together and strives to give concrete tools for reading enhancement to all educators.
\end{abstract}

\section{Keywords}

Reading Skills, Reading Enjoyment, Reading Attitudes

\section{Introduction}

Children's attitudes towards reading begin to form long before they become literate, and their experiences of success in the early stages of reading may have a far-reaching impact on their later attitudes toward reading (Suggate et al., 2013; Tompkins, 2011). A child who does not learn to read fluently and comprehend different kinds of texts in the early school years may have severe difficulties in school (Bowyer-Grane \& Snowling, 2005). Unfortunately, children with poor reading skills as first and second graders often continue to struggle with com- 
prehension in later years (Merisuo-Storm, 2010). This fact must be kept in mind when teaching young children, as the development of their reading skills in early years may have a long-lasting effect on their future abilities as learners.

Several studies (Brozo et al., 2008; Chiu \& McBride-Chang, 2006; Wigfield et al., 2008) show that engagement with reading and the length of time children spend reading for pleasure correlate significantly with their reading achievement. To motivate children to read we must find ways to stimulate their interest, bolster their confidence, and enhance their reading engagement. Children who have difficulties in learning to read soon begin to doubt their abilities as learners (Poikkeus et al., 2011). Poor readers do not enjoy reading and therefore spend less time reading than do fluent readers. Consequently, the difference between the levels of their reading skills becomes even greater and the results significant.

International assessments like the Programme for International School Assessment (PISA) and the Progress in International Reading Literacy Study (PIRLS) show that Finnish children have excellent reading skills. However, Finland shares a common concern with many other countries: girls outperform boys in reading. In every country assessed in PISA 2009, the number of boys in the low achievers' group was higher than the number of girls. To close the gender gap in reading performance, new ideas that aim to attract the interest and engagement of young boys with literature and help them to find pleasure in reading, are sorely needed (OECD, 2013; Välijärvi et al., 2007).

It is important to find ways to encourage children to read and to understand the obstacles behind any reluctance of reading. These two Finnish projects address this concern: JEKKU and LUKUINTO. JEKKU is an abbreviation of words Joustavienesi-ja alkuopetuskäytäntöjenkehittämisverkosto meaning Flexible Pedagogical Approaches in Pre- and Primary Education. The JEKKU-project was implemented in western Finland during the years 2010-2011 and the data of the project consists of 563 children (267 first-graders and 296 second-graders). The aim of the project was to find new ways for teachers to meet children's individual needs and to increase the experiences of happiness and success of children (Merisuo-Storm, Soininen, \& Aerila, 2012). The LUKUINTO-project means Bookish and was a national project conducted by the University of Oulu in Finland. It aimed at innovations to increase children's reading motivation and skills during years 2012-2015. Almost 15,000 children participated in different book projects (Lukuinto www-pages 2017). The Teacher Training School of Rauma and the Department of Teacher Education of the University of Turku participated in the projects as partners. Altogether 125 children and 6 teachers of Rauma Teacher Training School participated in our portion of the LUKUINTO-project. The children in the project were between 6 to 10 years. Juli-Anna Aerila and TuulaMerisuo-Storm worked as consultants and researchers in the JEKKU-project and Juli-Anna Aerila was a consultant and researcher also in LUKUINTO-project. These projects are complementary to each other, since the JEKKU-project consists mainly of quantitative results of different aspects of reading, and the LUKUINTO-project of different innovative and practical reading interventions 
in classrooms. Both projects were funded by the Finnish Board of Education.

This article presents different perspectives in helping children to enjoy reading more. The perspectives are supported by Finnish research but give concrete tools to the educators of all different cultures and languages.

\section{The Need for Good Reading Skills}

For readers, the most important goal is to understand what they read. They construct meaning by interacting with text, using their prior knowledge and experience and the information that can be found in the text (Brozo, 2010). While a fluent reader deals easily with issues of word recognition, appropriate pacing, phrasing, and intonation, a non-fluent reader's performance does not have all or perhaps any of these qualities. Rapid word identification and the construction and integration of meaning are essential in the reading process, however, for a non-fluent reader word identification demands mental capacity that would normally be dedicated to the comprehension process (Suggate et al., 2013). Only when reading material matches children's reading skills does it allow them to both enjoy and understand what they are reading (Allington \& Gabriel, 2012).

\section{Selecting reading material that meets students' reading abilities}

In the JEKKU-project, we evaluated the reading comprehension skills of eight year olds and the results show that there is a great difference in children's reading comprehension skills. Altogether 291 students read a nonfiction text about a squirrel and answered questions related to it. Answers to the easiest questions could be found in the text, but when answering the most difficult questions the children had to make connections that were not clearly expressed in the text. The easiest questions to answer proved to be the two questions that the children answered by choosing correct alternatives from a list. More than half of the students $(66 \%)$ found appropriate synonyms for all three words, and an equal number (65\%) found all three materials that the squirrels used when building their nests. The question, "What are the differences between squirrel's summer fur and winter fur?" indicates that there are more than one difference. Still, less than a third of the students (30\%) mentioned both (colour and thickness). To answer the most difficult questions the students needed to make connections that were not clearly expressed in the text. They were asked: "Where are the seeds of a pine and fir tree?" and "Why does the squirrel hide its food?" Only $15 \%$ of girls and $11 \%$ of boys answered the question about the seeds and $27 \%$ of girls and $19 \%$ of boys the question about the food correctly (Merisuo-Storm \& Soininen, 2012).

These results highlight the differences in reading skill already in early ages. It is essential to provide young readers with interesting reading material that meets their reading abilities. If readers are interested in the content, they want to understand it, which will in turn, stimulate processes that are important in comprehension, such as making inferences based on the text and on readers' previous knowledge. However, young readers should learn to use appropriate com- 
prehension strategies in different reading situations like previewing, activating prior knowledge, predicting, making connections, monitoring, organizing, summarizing, questioning, and visualizing (Merisuo-Storm \& Soininen, 2016a). These strategies are necessary because they can supply access to knowledge that is beyond young readers' personal experience (McLaughlin, 2006; Stahl, 2004).

When struggling readers read, their poor mechanical reading skills may demand all their mental capacity. Reading comprehension skills can improve when they listen to the teacher reading. The teacher's fluent reading helps them to concentrate on the interpretation and metacognitive details that the text demands (Damber, 2015; Jacobs et al., 2000). In LUKUINTO-project eighth-graders read children's literature several times a week to first-graders. Our observations during this one-month experiment and interviews with the students indicate that these exercises benefit both the older and younger children. Those eighth-graders who still have poor reading skills had opportunities to read books that were not as difficult as the texts they usually read at school. During the project their self-confidence was stronger than when reading to their own classmates. The first-graders, meanwhile, had the opportunity to listen to stories read by more advanced readers, discuss the stories with them, and have the undivided attention of an older student (Aerila \& Merisuo-Storm, 2017).

Children are willing to undertake demanding tasks if they are in an environment which supports them, individually. Motivation and achievement beliefs are especially important when tasks become more challenging. However, the motivation of those students whose skills are well developed may decrease if they regularly have to do exercises that are too easy or too difficult for them (Georgiou et al., 2010).

Giving children experiences of success while reading

The results of the JEKKU-project show a strong interdependence between first- and second-graders' reading skills, their attitudes towards reading and studying, and their self-esteem. The results revealed that children who had a positive attitude towards reading also enjoyed studying. There was a strong correlation between students' self-esteem, reading attitudes, and reading comprehension skills; those with good self-esteem had positive attitudes towards reading and good reading comprehension skills. The results suggest that good self-esteem is even more closely related to attitudes towards studying for boys, than for the girls (Merisuo-Storm \& Soininen, 2012). As important as it is for first- and second-graders to acquire good reading skills, it is entirely possible that learning to read has positive effects on self-esteem. Students who are confident and happy with who they are, tend to get along well with other children and enjoy studying.

It is important to provide reluctant readers with experiences of success while reading and to help make the learning process positive and motivating. Children who have difficulties in literacy learning, experience anxiety during reading assignments (Poikkeus et al., 2011). Reading aloud in class appears to be a task that 
frightens students, even skilled and eager readers. The results in JEKKU-project showed that in the second grade almost one quarter of boys (23\%) and $12 \%$ of girls found reading aloud in the class frightening and embarrassing (Merisuo-Storm \& Soininen, 2016b). It is important, that the teachers find ways to create safe reading environments in which all children can read without worrying about the kind of criticism.

A reading intervention known as canine-assisted literacy has proved to increase children's reading fluency and motivation, providing encouragement for struggling readers, and making reading fun for students in general (Jalongo, 2004; Lane \& Zavada, 2013). Controlled studies investigating reading skills of children while reading aloud with dogs report improved reading comprehension in the students reading to a dog (Le Roux, Swartz, \& Swartz, 2014). Recent studies suggest an increase of a hormone, oxytocin present during the human-animal bond that promotes positive mood, trust, and social interaction including communication (Fine, 2011; Gee et al., 2017). In such an animal-assisted activity children read to an animal, typically a specially trained dog. Children who feel uncomfortable when reading to adults or to other children are often quite happy to read to a dog, perhaps because the dogs do not criticize their performance or make them feel bad (Jalongo, 2012). Reading programs that include the presence of dogs have been investigated using pre/post measurement control-group designs (Le Roux, Swartz, \& Swart, 2014).

In the LUKUINTO-project, first graders were asked to read aloud with a certified reading dog during a school lesson. After the experiment they reported that it was easier than reading to another child or the teacher and that they felt less agitated and nervous while reading. In their opinion, it was easier to concentrate on reading because the dog listened patiently and allowed them to proceed at their own pace. The children enjoyed spending time with an animal because they did not usually have opportunities to show their feelings or play during school days. All the children concluded that if the dog fell asleep while listening, that was a sign of a successful reading session (Aerila \& Merisuo-Storm, 2017a).

Allotting time for simply reading at school

In JEKKU-project, almost all first- and second-graders (93\% in both cases) reported liking reading books and enjoying visits to the library (Merisuo-Storm \& Soininen, 2013). Most children value reading and would read more if they had time (Ivey \& Broaddus, 2001). However, as children get older, they become engaged in extra-curricular activities and it becomes more challenging to find time for reading at home. Reading at schools is an important means of ensuring equal opportunity for all students. It is important to give students enough time for simply reading at school and offer frequent opportunities to visit the library. If we want children to read, we should have them actually read rather than perform a variety of tasks (Allington \& Gabriel, 2012).

In Finnish schools, children are often encouraged to read if they have time after they have finished their assignments. This is an effective practice for advanced readers but struggling and reluctant readers seldom have that time or 
may not want to find the time to read, if they want to read at all. Nice reading locations nurture feelings of pleasure in reading. In the LUKUINTO-project, we decided to invest more time in reading. At the beginning of the experiment, we investigated second-graders' opinions about appropriate and comfortable reading places. They reported wanting a quiet, comfortable place where they could concentrate. The children tested four physical settings: the first reading venue was a traditional classroom, where children sat at tables while reading. The second venue was a classroom with a sofa, armchairs, soft rugs, and table lamps, and students were allowed to choose where to read. The third room had soft pillows on the floor, while the fourth was furnished with very large cardboard boxes converted into "cottages" with doors and windows that could accommodate two readers each. The overwhelming favorite was the cardboard-box cottages, while they liked the ordinary classroom least (Figure 1). The children emphasized that being able to choose their reading place was important because a place without distractions helped them concentrate on reading (Aerila et al., 2015).

\section{Versatile Reading Material Is Essential}

Not all children like reading the same books. It is especially important that struggling readers find the topic of a text interesting. Therefore, it is essential to offer a wide range of reading material on various topics with different levels of difficulty and literary genres. Teachers should also consider reading texts that are not commonly part of the school setting; it may be that a boy who dislikes reading at school quite happily uses reading for many purposes outside school and feels more able to read texts that he has selected himself (Brozo, 2002).

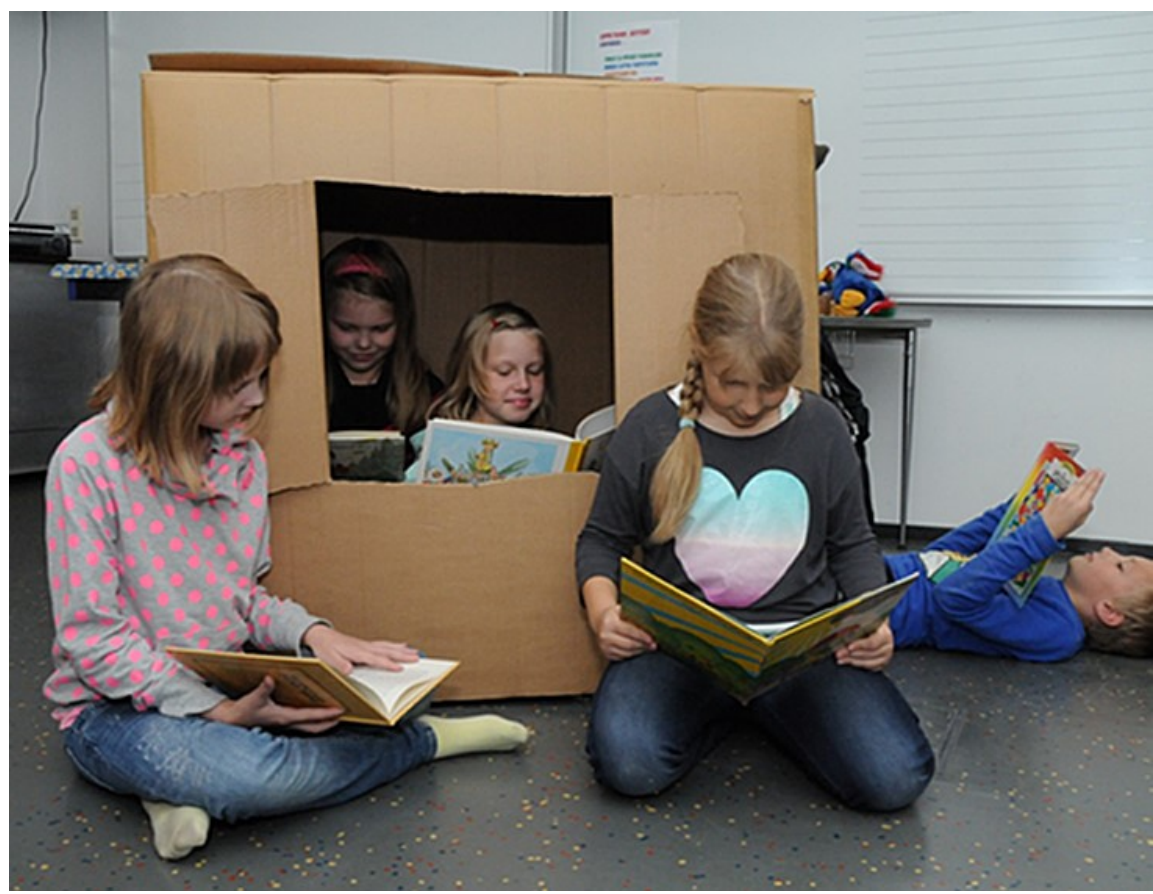

Figure 1. Reading time in a cardboard box "reading cottage". 


\section{Do not force all students to read the same books}

We must keep in mind that although adults tend to use book types or genres as the main criteria when selecting books for children, it is more important that books appeal to them and are connected to their interests. Even in the first grade, it is already necessary to teach children to think critically about what they read and help them appreciate the benefits of reading both fiction and nonfiction (Aerila \& Merisuo-Storm, 2016). Child-centered approaches include offering student's choices within a wide range of genres and formats, levels and topics of what they read. Wilkinson (2003) and Weigel et al. (2006) suggest that adults should put aside their own preconceptions of what books are good reading material and not force children into narrow definitions of what books are suitable and worth reading for them. Chapman et al. (2007) emphasise that children need a varied genre selection even in the early school years; narratives provide them with stories and demonstrate the power of creativity, while histories expose them to their cultural patrimony. While fiction nurtures children's identities and imagination, nonfiction develops children's knowledge of the world and enhances their language and comprehension skills.

Chapman et al. (2007) examined what kind of books Canadian first-graders prefer to read. The results showed no differences in girls' and boys' choices, and both genders were equally interested in fictional and nonfiction books. The criteria the students used included attractive illustrations, an interesting topic, and humour. When the students were asked to choose books for another boy and girl, they chose narrative books for girls and nonfiction for boys, suggesting that first-graders had already formed gender-stereotyped opinions of the books that boys and girls like to read, even though their own interests were not consistent with those stereotypes.

We wanted to replicate the experiment in two first- and two second-grade classes in Finland, for which we chose five pairs of books. In each pair, there was a narrative book and a nonfiction book on the same theme: squirrels, mummies, spies, elephants, and outer space. The results of our study were similar to what Chapman et al. found; there was no difference in girls' and boys' favorites when choosing books for themselves; both genders tended to choose nonfiction books. However, when they chose fiction for others, they chose fiction for girls and nonfiction for boys.

\section{Remember that boys can also enjoy reading}

Boys like to read books describing their favorite sports and other interests and show a tendency for reading historical fiction. Furthermore, boys often choose books targeted for older readers and books featuring characters they admire or with whom they can identify (Brozo, 2002). Whatever the topic or genre, reading material must capture boys' attention: it has to be attractive, colourful, and dramatic and include interesting events, with characters featuring a certain level of prestige or ability. Reading fiction outside literature lessons can improve content learning. Literature can provide a meaningful context in which to develop ma- 
thematical skills, especially in early childhood education (Billings \& Beckmann, 2005).

When children are allowed to choose their own reading material, many boys and struggling readers decide to read comics. Comics combine pictures and words, giving visual cues as to what the text is discussing and thus helping children to understand what they read. This genre is often familiar from the earliest years of their reading lives. The pleasure from reading comics is associated with a feeling of ownership of the text, a feeling that gives a reader the confidence to engage actively with different texts-comics in this case-and assess them critically. In addition, children like to discuss the events in comics with their peers (Norton, 2003; Viadero, 2009). In addition, comics improve children's visual literacy skills, which they need to comprehend information they gather on the Internet, among other uses (McVicker, 2007).

It is worth considering whether teachers could use comics as reading materials also at school. Even though many teachers hold the opinion that comics are not good literature, the Finnish edition of Donald Duck magazine received the 2001 Language Gem of the Year award from the Department of Finnish at the University of Helsinki for its high quality and ingenious language.

\section{Reading Is a Social Activity}

Current research in the cognitive sciences strongly supports the theory that learning is shaped by social interactions (Cozolino, 2013). It is exciting to discover how teachers have at their fingertips ways and means of helping young learners cultivate and develop these interactions through activities designed for learning and sharing together with peers. Also the results of the LUKUINTO-project (Aerila et al., 2014) indicate that for many children, especially boys, the most unpleasant part of reading is sitting still and feeling alone.

Offer students frequent opportunities to enjoy one another's company (Grand Conversations)

In LUKUINTO-project the second-graders read in pairs, with each pair choosing a book from a large selection in accordance with their own interests and literacy skills. In addition, they were allowed to determine the length of the text they read and the physical space in which the reading took place. The interviews after the reading sessions show that the children enjoyed reading in pairs. According to them, reading in pairs is fun and it is enjoyable to laugh together when the events in a story are funny. They also appreciated the opportunity to discuss with their partners, things like the reading experience, similar observations, and the general value of reading. The teachers' opinion was that the best feature of the experiment was the relaxed atmosphere and the students' feeling of togetherness (Aerila \& Merisuo-Storm, 2017). Boys in particular could benefit from discussions in groups that consist of both boys and girls. It seems that when reading stories, girls are more sensitive and understand the personalities and feelings of the characters more easily than boys; they also pay attention to 
the surroundings of where the characters live. The boys appear to focus their attention more on the events of a story (Merisuo-Storm \& Soininen, 2016).

Reading circles or reading pairs are motivating methods to enhance children's reading. Reading circles can be used as a part of literature discussions, as a method for the reading activity itself, or both. Reading circles appear to be especially helpful for boys, because some boys need an opportunity to discuss their thoughts to reassure them that they have understood a text correctly (Brozo, 2014).

Provide motivating and social ways to practice different components of reading

Reader's Theatre proved to offer an effective method in LUKUINTO-project. However, the younger the students are, the more they need guidance and practice when preparing the performance. Most children who took part in Reader's Theatre in LUKUINTO-project were in the second grade. The teacher supported the children's performances by revising the manuscripts in accordance with their individual reading skills, by modelling the process of reading performance, and by giving the children props to liven up their performance. The children liked this reading method, even though some of them still had rather poor reading skills. After repeated readings, their reading became more fluent. In addition, the children value the Reader's Theatre approach as a safe way to practice performing in front of others (Aerila \& Rönkkö, 2015).

At the Reader's Theatre, the students prepare an oral interpretation of a text by means of drama or skits. The performance consists of the text, different gestures and motions, and a limited number of carefully selected other elements such as props and stage art. The Reader's Theatre method demonstrates how reading aloud enhances students' reading fluency and comprehension skills and helps readers understand different elements of a text, such as the narrator or the characters. Repeated readings encourage the reader to focus on interpretation instead of mechanical reading. Furthermore, as readers act while reading, they pay attention to articulation, pronunciation, fluency, and any mental images that may arise (Black \& Stave, 2007; Goodson \& Goodson, 2005).

Enhance family literacy and a positive appreciation of reading at home

In the LUKUINTO-project third-graders and their parents were asked to write about their children's experiences in reading and learning to read. The children's attitudes towards reading and learning to read were mainly positive. The children's most positive experiences were related reading with fathers or grandfathers. We decided to invite their fathers and grandfathers to school to read (Aerila \& Merisuo-Storm, 2017).

There were significant differences between these reading sessions. Several readers chose to let the teacher decide what they would read, then read it without preparing their performance in any way and left after the reading. They chose the reading material carefully and explained why they had decided to read this particular book. In addition, they discussed the theme of the book and the contents of the story with the children. The children whose family members 
were present were happy about the experiment, while others hoped that the project would continue so that their family members could also take part. There were several memorable reading sessions. In one of them, a grandfather read sports news about the local ice hockey team to a group of boys and talked with them about his ideas about ice hockey and the importance of newspapers (Figure 2) (Aerila \& Merisuo-Storm, 2017).

Family literacy includes combining parents, children, and formal education, and it can positively affect the amount of reading at home (Timmons \& Pelletier, 2015). The parents and grandparents in our project were surprised at how enthusiastically the children listened to their reading. This gave them confidence in their efforts to support the development of their children's literacy skills (Aerila \& Merisuo-Storm, 2017), Padak and Rasinski (2008) present explicit and simple guidelines to enhance family literacy, from how to choose reading material to what kind of reading techniques can be employed. It is vital to remember that reading is a reciprocal activity: sometimes the adult reads and the child listens, and sometimes the roles are reversed. Shared book reading should also include discussions, comments, and questions about the text.

\section{Activate the interpretation of literature}

The results of JEKKU-project show that even in the first grade, children may regard doing exercises during literacy lessons as unpleasant chores; this was especially true of the boys. One quarter of the boys (24\%) in the first grade and one third (33\%) of the boys in the second grade reported that they "hated" doing these exercises. Similarly, they often had negative opinions about homework. 25\% of first-grade and $25 \%$ of second-grade boys "hated" homework; they did not want to do tasks that they did not consider meaningful (Merisuo-Storm \& Soininen, 2012).

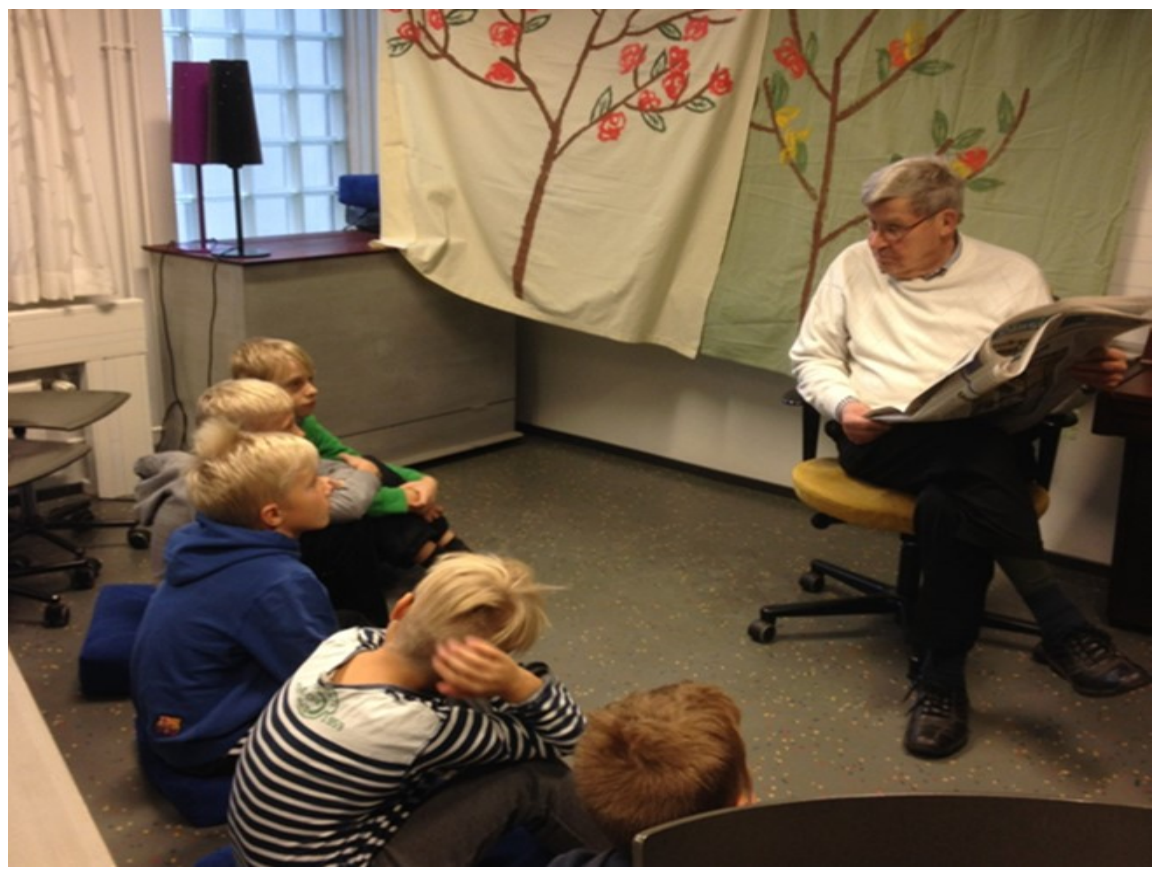

Figure 2. A grandfather reading sports news to children. 
It is important to ensure that reading in school does not simply become completing assignments. Even if many students' attitudes towards traditional fill-in-the-blank or short-answer response tasks are negative, they are more motivated to read if reading has a clear goal.

Activating assignments and students' collaboration enhance their reflections upon and interpretation of reading. Different forms of arts combined with literature have proved to meet the needs of reluctant readers particularly well (Brozo, 2002; Molloy, 2007; Wilhelm, 2008). Different assignments completed in small groups can aim at concrete outcomes. We have successfully used literature-based individual story endings (ISE) as assignments. ISE means creating a personal story ending to a fragment of a fictional text. It is an activity that can be implemented through various art-based approaches in different modes: dramatizing, writing a story, drawing, or making a short movie. The aim is to produce a text that accords with the original text in terms of substance and style (Aerila \& Rönkkö, 2015).

When implementing ISE as a pedagogical approach, it is important to obey a few guidelines. The original story must be cut off at a turning point in the plot, and the teacher should not offer any clues as to how the students should proceed or which details in the story matter the most. In short, the closer the students' endings resemble the ending of the original story, the more skillfully they have been able to infer from clues provided in the text how the story is likely to end. In our studies, we have also used follow-up stories as a tool for visualizing children's values and content knowledge. The results of using ISE as a pedagogical approach indicate that children enjoy inventing personal story endings, comparing them, and having discussions about them. Because children's story endings visualise their thoughts, the lessons become more child-centred (see e.g. Aerila \& Rönkkö, 2015).

\section{Conclusion}

By offering multiple means of engagement and interaction, utilizing interesting books at appropriate levels for all, young readers can continue to enjoy reading and discover enjoyable, meaningful ways to develop their reading skills. Variety and choice of interaction with reading materials, and social activities such as reading circles, Readers Theatre, reading with peers, reading in pairs, and reading aloud to a dog, have been shown to stimulate motivation to read and to help sustain interest.

The results of the JEKKU-project show that there is strong interdependence between first- and second-graders' reading skills, attitudes towards reading and studying, and self-esteem. Students with good self-esteem have positive attitudes towards reading and develop good reading skills. In addition, good self-esteem is even more closely related to boys' attitudes towards reading and studying than it is for girls.

However, even children with good reading skills may be nervous if they are asked to read aloud in class. In the LUKUINTO-project, we found two effective 
solutions to this problem. First, when older students are able to read to younger students, they have opportunities to read books that are not as difficult as the books they are typically assigned in their own classes, and the younger students do not criticize their reading, strengthening the older readers' self-confidence as readers. Second, children find animals to be much easier listeners than other students or teachers. They listen patiently and quietly, without judgment, even if the reader reads slowly, makes mistakes, and reads the same text several times. All students enjoy reading with a dog.

Another way to give students more reading practice is the Reader's Theatre method. During repeated readings while rehearsing the performances for the reader's theatre, the students' reading becomes more fluent. Furthermore, reading circles and reading in pairs provide each student with more practice in reading than reading in the classroom alone. Students enjoy reading with a peer, laughing together when the events in the story are funny, and discussing their reading experiences. Furthermore, the discussions with girls may help boys to become more sensitive readers and begin to understand the personalities and feelings of the characters more fully.

The grandfathers' and fathers' visits to schools are advantageous in, at least, two ways. First, the children enjoyed these readings immensely and the grandfathers and fathers gave the boys a model of a male reader. For instance, in our study one grandfather succeeded in convincing the boys-all children of the Internet age-that newspapers were worth reading. Second, the visits proved to be an excellent means of enhancing family literacy. The shared book readings include the elements of dialogic reading such as discussions, comments, and questions about the text. Reading at school gave the grandparents and fathers the confidence and encouragement to continue readings of this kind at home and how to put it in practice there.

Additionally, teachers should discuss the texts that are read with children more often. The results of our reading comprehension tests in the JEKKU-project show that teachers do not spend enough time discussing what has been read. When aiming to develop children's reading comprehension skills, teachers tend to rely on direct oral questioning, which usually produces correct but predictable answers, and do not encourage children to develop more elaborate questions and ideas. Even if the range of questions is wide and appropriate, the children's role can still be too passive. Shared discussions about the texts help the children to understand a text as a whole, rather than as a combination of scattered details. However, if the discussions are based only on the teachers questions, children do not learn to think for themselves or find their own interpretations, in order to become more closely involved with the literature.

The students need reading places where they can read without distractions. In the LUKUINTO-project, the children's favourite places were reading "cottages" made of cardboard boxes. They were cozy places where the students enjoyed reading together with another child, showing that children do not need elaborate reading environments as much as they like privacy and peace when reading. The 
children emphasize that being able to choose where they would read is important because a place without distractions helps them to concentrate on reading.

It is important to provide young readers with interesting reading material that meets their reading abilities. When they are allowed to read material that is relevant to their lives, children become engaged readers. Children should also be allowed to give their opinions when the teacher chooses reading material for them. Reluctant readers can be attracted to read if they themselves can choose or help to choose what they read. For instance, reading comic books can strengthen students' confidence in their reading comprehension skills. Because boys often prefer nonfiction books, the teacher should make the effort to find fiction that contains information of interest to boys. It is especially important that the teacher discover what interest the reluctant readers; it is possible for reading to be enjoyed by all children. Teachers realize they can trust young readers to find what is appropriate for themselves. They will find the genre and material they love when a wide range of reading levels and genre are provided for them.

\section{Discussion}

Relationships are our natural habitat (Cozolino, 2013). Throughout the JEKKU and LUKUINTO Projects we described the presence of many factors that build relationships in a variety of ways. A key constituent woven in all the findings was trust: trust of students to make choices and trust in the teachers themselves, to listen to the children. There were many relationships: students learning in relationship with themselves (discovering the power of choice and developing their own questions and ideas), relationships with peers, with animals (reading to a dog who does not judge them), students in relationship with their teachers who see them as holders of knowledge too, students in relationship with engaging literature and materials (in which they experience the trans-active nature of reading itself), relationships with creative activities shared together, and relationships with environments that are comfortable and quiet, and relationships with reading activities with multi-genre literature. We hope that these examples from our research may provide inspiration and encouragement for others in discovering ways to increase student engagement in reading and thereby the joy and delight in experiencing reading successes.

\section{References}

Aerila, J.-A., \& Merisuo-Storm, T. (2016). Lukupolkuja. Muutama vekkuli vinkki lukemisen lisäämiseen. [Road to Reading. A Couple of Inspiring Advices to Read More.] Kielikukko, 20-27.

Aerila, J.-A., \& Rönkkö, M.-L. (2015). Enjoy and Interpret Picture Books in a Child-Centred Way. The Reading Teacher, 68, 349-356.

https://doi.org/10.1002/trtr.1313

Aerila, J.-A., Niinistö, E.-M., Kallio H., Heino, S., \& Äimälä, P. (2014). Lukuintoaetsimässä. [Looking for the Joy of Reading.] In P. Atjonen, H. Happonen, J. Korkki et al., (Eds.), Ohjausta, harjoittelua ja oppimista. Teoria ja käytäntö ohjatussa harjoittelussa [Guidance, Training and Learning: Theory and Practice in Guided Training.] (pp. 
110-125). Joensuu, Finland: University of Eastern Finland, Teacher Training School of Joensuu.

Allington, R. L., \& Gabriel, R. E. (2012). Every Child, Every Day. Reading: The Core Skills, 69, 10-15.

Billings, E., \& Beckmann, C. (2005). Children's Literature: A Motivating Context to Explore Functions. Mathematics Teaching in the Middle School, 10, 470-478.

Black, A., \& Stave, A. (2007). A Comprehensive Guide to Readers Theatre: Enhancing Fluency and Comprehension in Middle School and Beyond. Newark, NJ: International Reading Association.

Bowyer-Grane, C., \& Snowling, M. (2005). Assessing Children's Inference Generation: What Do Tests of Reading Comprehension Measure? British Journal of Educational Psychology, 75, 189-201. https://doi.org/10.1348/000709904X22674

Bowyer-Grane, C., \& Snowling, M. J. (2005). Assessing Children's Inference Generation: What Do Tests of Reading Comprehension Measure? British Journal of Educational Psychology, 75, 189-201. https://doi.org/10.1348/000709904X22674

Brozo, W. (2002). To Be a Boy, to Be a Reader. Engaging Teen and Preteen Boys in Active Literacy. Newark, DE: International Reading Association.

Brozo, W. (2010). The Role of Content Literacy in an Effective RTI Program. The Reading Teacher, 64, 147-150. https://doi.org/10.1598/RT.64.2.11

Brozo, W. (2014) Presentation. Helsinki, Finland. http://www.lukukeskus.fi/lukutaitotutkija-william-g-brozo-vieraili-suomessa/

Brozo, W., Shiel, G., \& Topping, K. (2008). Engagement in Reading: Lessons Learned from Three PISA Countries. Journal of Adolescent \& Adult Literacy, 51, 304-315. https://doi.org/10.1598/JAAL.51.4.2

Chapman, M., Filipenko, M., \& McTavish, M. (2007). First Graders' Preferences for Narrative and/or Information Books and Perceptions of Other Boys' and Girls' Book Preferences. Canadian Journal of Education/Revue canadienne de l'éducation, 30, 531-553. https://doi.org/10.2307/20466649

Chiu, M., \& McBride-Chang, C. (2006). Gender, Context, and Reading: A Comparison of Students in 43 Countries. Scientific Studies of Reading, 10, 331-362. https://doi.org/10.1207/s1532799xssr1004_1

Cozolino, L. (2013). The Social Neuroscience of Education: Optimizing Attachment and Learning in the Classroom. New York: W.W. Norton \& Company, Inc.

Damber, U. (2015). Read-Alouds in Preschool-A Matter of Discipline? Journal of Early Childhood Literacy, 15, 256-280. https://doi.org/10.1177/1468798414522823

Fine, A. H. (2011). Handbook on Animal-Assisted Therapy: Theoretical Foundations and Guidelines for Practice. New York, NY: Elsevier Science.

Gee, N., Fine, A. H., \& McCardle, P. (2017). How Animals Help Students Learn. New York, NY: Routledge.

Georgiou, G., Manolitsis, G., Nurmi, J.-E., \& Parrila, R. (2010). Does Task-Focused versus Task-Avoidance Behaviour Matter for Literacy Development in an Orthographically Consistent Language? Contemporary Educational Psychology, 35, 1-10. https://doi.org/10.1016/j.cedpsych.2009.07.001

Goodson, F., \& Goodson, L. A. (2005). You Oughta Use the Periods and Stuff to Slow Down: Reading Fluency trough Oral Interpretation of YA Lit. Voices from the Middle, 13, 24-29.

Ivey, G., \& Broaddus, K. (2001). “Just Plain Reading”: A Survey of What Makes Students 
Want to Read in Middle Schools. Reading Research Quarterly, 36, 350-377. https://doi.org/10.1598/RRQ.36.4.2

Jacobs, J., Morrison, T., \& Swinyard, W. (2000). Reading Aloud to Students: A National Probability Study of Classroom Reading Practices of Elementary School Teachers. Reading Psychology, 21, 171-193. https://doi.org/10.1080/02702710050144331

Jalongo, M. (2004). Canine Visitors, the Influence of Therapy Dogs on Young Children's Learning and Well-Being in Classrooms and Hospitals. Early Childhood Education Journal, 32, 9-16. https://doi.org/10.1023/B:ECEJ.0000039638.60714.5f

Jalongo, M. (2012). An Attachment Perspective on the Child-Dog Bond: Interdisciplinary and International Research Findings. Early Childhood Education Journal, 43, 395-405.

Lane, H. B., \& Zavada, S. (2013). When Reading Gets Ruff: Canine-Assisted Reading Programs. The Reading Teacher, 67, 87-95. https://doi.org/10.1002/TRTR.1204

Le Roux, M. C., Swartz, L., \& Swartz, E. (2014). The Effect of an Animal-Assisted Reading Program on the Reading Rate, Accuracy and Comprehension of Grade 3 Students: A Randomized Controlled Study. Child Youth Care Forum, 43, 655-673. https://doi.org/10.1007/s10566-014-9262-1

McLaughlin, M. (2006). Guided Comprehension in the Primary Grades. Newark, DE: International Reading Association.

McVicker, C. (2007). Comic Strips as a Text Structure for Learning to Read. The Reading Teacher, 61, 85-88. https://doi.org/10.1598/RT.61.1.9

Merisuo-Storm, T. (2010). Literacy Skills and Learning Attitudes in Bilingual Education. In The National Institute of Educational Resources and Research, Educational Theory and Practice in Finland (pp. 241-266). Taipei: The National Institute of Educational Resources and Research.

Merisuo-Storm, T., \& Soininen, M. (2012). Constructing a Research-Based Program to Improve Primary School Students' Reading Comprehension Skills. International Journal for Cross-Disciplinary Subjects in Education (IJCDSE), 3, 755-762.

https://doi.org/10.20533/ijcdse.2042.6364.2012.0108

Merisuo-Storm, T., \& Soininen, M. (2013). Interesting Reading Materials and Exercises Encourage Also Reluctant Boys to Read. Procedia-Social and Behavioral Sciences, 116, 2583-2588. https://doi.org/10.1016/j.sbspro.2014.01.615

Merisuo-Storm, T., \& Soininen, M. (2016). The Interdependence between Young Students' Reading Attitudes, Reading Skills, and Self-Esteem. Journal of Educational and Social Research, 4, 122-130.

Merisuo-Storm, T., Soininen, M., \& Aerila, J.-A. (2012). JEKKU-Project. Turku: The University of Turku.

Molloy, G. (2007). När pojkar läser och skriver. [When Boys Read and Write]. Lund: Studentlitteratur.

Norton, B. (2003). The Motivating Power of Comic Books: Insights from Archie Comic Readers. The Reading Teacher, 57, 140-147.

OECD (Organisation for Economic Co-Operation and Development) (2013). PISA 2012 Results in Focus. What 15-Year-Olds Know and What They Can Do with What They Know. Paris: OECD.

Padak, N., \& Rasinski, T. (2008). Is Being Wild about Harry Enough? Encouraging Independent Reading at Home. The Reading Teacher, 61, 350-353.

https://doi.org/10.1598/RT.61.4.9

Poikkeus, A.-M., Lerkkanen, M.-K., \& Rasku-Puttonen, H. (2011). The Role of Classroom Interactional Quality and Teaching Practices in the Development of Children's Aca- 
demic Skills and Motivation: Findings from the First Steps Study. In M. Kontoniemi, \& O.-P. Salo (Eds.), Educating Teachers in the PISA Paradise: Perspectives on Teacher Education at a Finnish University (pp. 67-86). Jyväskylä: University of Jyväskylä, Teacher Training School.

Stahl, K. (2004). Proof, Practice, and Promise: Comprehension Strategy Instruction in the Primary Grades. The Reading Teacher, 57, 598-609.

Suggate, S., Schaughency, E., \& Reese, E. (2013). Children Learning to Read Later Catch up to Children Reading Earlier. Early Childhood Research Quarterly, 28, 33-48. https://doi.org/10.1016/j.ecresq.2012.04.004

Timmons, K., \& Pelletier, J. (2015). Understanding the Importance of Parent Learning in a School-Based Family Literacy Programme. Journal of Early Childhood Literacy, 15, 510-532. https://doi.org/10.1177/1468798414552511

Tompkins, G. E. (2011). Literacy in the Early Grades: A Successful Start for PreK-4 Readers and Writers. Boston, MA: Pearson.

Välijärvi, J., Kupari, P., Linnakylä, P. et al. (2007). The Finnish Success in PISA and Some Reasons behind It 2. Jyväskylä: University of Jyväskylä, Institute for Educational Research.

Viadero, D. (2009). Scholars See Comics as No Laughing Matter. Education Week, 28, $1-11$.

Weigel, D., Martin, S., \& Bennett, K. (2006). Mothers' Literacy Beliefs: Connections with the Home Literacy Environment and Pre-School Children's Literacy Development. Journal of Early Childhood Literacy, 6, 191-211. https://doi.org/10.1177/1468798406066444

Wigfield, A., Guthrie, J. T., Perencevich, K., Taboada, A., Klauda, S., McRae, A., \& Barbosa, P. (2008). Role of Reading Engagement in Mediating Effects of Reading Comprehension Instruction on Reading Outcomes. Psychology in the Schools, 45, 432-445. https://doi.org/10.1002/pits.20307

Wilhelm, J. (2008). "You Gotta BE the Book": Teaching Engaged and Reflective Reading with Adolescents. New York, NY: Teachers College Press.

Wilkinson, K. (2003). Children's Favourite Books. Journal of Early Childhood Literacy, 3, 275-301. https://doi.org/10.1177/1468798403033004 